\title{
Thermodynamic Modeling Suggests Declines in Water Uptake and Acidity of Inorganic Aerosols in Beijing Winter Haze Events during 2014/2015- 2018/2019
}

\section{Citation}

Song, Shaojie, Athanasios Nenes, Meng Gao, Yuzhong Zhang, Pengfei Lui, et at.

"Thermodynamic Modeling Suggests Declines in Water Uptake and Acidity of Inorganic Aerosols in Beijing Winter Haze Events during 2014/2015-2018/2019." Environmental Science \& Technology Letters 6, no. 12 (2019): 752-760.

\section{Permanent link}

http://nrs.harvard.edu/urn-3:HUL.InstRepos:42354467

\section{Terms of Use}

This article was downloaded from Harvard University's DASH repository, and is made available under the terms and conditions applicable to Open Access Policy Articles, as set forth at http:// nrs.harvard.edu/urn-3:HUL.InstRepos:dash.current.terms-of-use\#OAP

\section{Share Your Story}

The Harvard community has made this article openly available.

Please share how this access benefits you. Submit a story.

\section{Accessibility}


1 Thermodynamic Modeling Suggests Declines in Water Uptake and 2 Acidity of Inorganic Aerosols in Beijing Winter Haze Events during 3 2014/2015-2018/2019

Shaojie Song, ${ }^{\dagger, \downarrow}$ Athanasios Nenes,,${ }^{\S, \mathfrak{t}}$ Meng Gao,${ }^{\ddagger}$ Yuzhong Zhang, ${ }^{\ddagger}$ Pengfei Liu,${ }^{\ddagger}$ Jingyuan Shao, ${ }^{\perp}$ 6 Dechao Ye, ${ }^{\dagger}$ Weiqi Xu, ${ }^{\#}$ Lu Lei,, ${ }^{\#}$ Yele Sun,, ${ }^{\#, *}$ Baoxian Liu, ${ }^{\dagger, l,{ }^{*}}$ Shuxiao Wang, ${ }^{\dagger, *}$ Michael B. 7 McElroy

†School of Environment, Tsinghua University, Beijing 100084, China

11 02138, USA

12 SSchool of Architecture, Civil and Environmental Engineering, Ecole Polytechnique Fédérale de 13 Lausanne, CH-1015, Lausanne, Switzerland

14 f Institute for Chemical Engineering Sciences, Foundation for Research and Technology Hellas, 15 Patras, GR-26504, Greece

$16{ }^{\perp}$ School of Physics, Peking University, Beijing 100871, China

17 "State Key Laboratory of Atmospheric Boundary Physics and Atmospheric Chemistry, Institute of 18 Atmospheric Physics, Chinese Academy of Sciences, Beijing 100029, China

19 "Beijing Key Laboratory of Airborne Particulate Matter Monitoring Technology, Beijing Municipal Environmental Monitoring Center, Beijing 100048, China

\section{ABSTRACT}

23 During recent years, aggressive air pollution mitigation measures in northern China have resulted

24 in considerable changes in gas and aerosol chemical composition. But it is unclear whether aerosol

25 water content and acidity respond to these changes. The two parameters have been shown to affect

26 heterogenous production of winter haze aerosols. Here, we performed thermodynamic equilibrium

27 modeling using chemical and meteorological data observed in urban Beijing for four recent winter

28 seasons and quantified the changes in the mass growth factor and $\mathrm{pH}$ of inorganic aerosols. We

29 focused on high relative humidity ( $>60 \%)$ conditions when submicron particles have been shown

30 to be in the liquid state. From 2014/2015 to 2018/2019, the modeled mass growth factor decreased

31 by about $9 \%-17 \%$ due to changes in aerosol compositions (more nitrate and less sulfate and 
32 chloride) and the modeled $\mathrm{pH}$ increased by about $0.3-0.4$ unit mainly due to rising ammonia. A

33 buffer equation is derived from semivolatile ammonia partitioning, which helps understand the

34 sensitivity of $\mathrm{pH}$ to meteorological and chemical variables. The findings provide implications for

35 evaluating the potential chemical feedback in secondary aerosol production and the effectiveness

36 of ammonia control as a measure to alleviate winter haze.

\section{1. INTRODUCTION}

38 One ubiquitous component of ambient aerosols is condensed water, which partitions to particles

39 from water vapor. ${ }^{1}$ The abundance of aerosol-phase water primarily depends on relative humidity

40 (RH), particle mass, and chemical composition. ${ }^{2}$ Aerosol water contributes to aerosol mass, ${ }^{3}$ alters

41 physical properties, ${ }^{4,5}$ facilitates gas-to-particle uptake of semivolatile species, ${ }^{6}$ and provides the

42 medium for heterogeneous (multiphase) processes. ${ }^{7-9}$ Studies have suggested that aerosol water

43 plays a role in the formation of northern China winter haze, a serious public health issue. ${ }^{10-13} \mathrm{~A}$

44 positive feedback mechanism has been proposed, ${ }^{12}$ in which aerosol water promotes secondary

45 aerosol production and the product aerosols, in turn, enhance water uptake. Aerosol water content

46 and acidity (or $\mathrm{pH}$ ) are considered as two influencing parameters, with the first representing the

47 space for heterogeneous processes and the second determining rates of many chemical reactions. ${ }^{14-}$

$48{ }^{18}$ Hence, it is useful to characterize these two parameters for understanding haze formation.

49 A general approach to measuring aerosol water content is by perturbing $\mathrm{RH}$ and detecting the

50 changes in aerosol physical properties, e.g., using nephelometers or hygroscopicity tandem

51 differential mobility analyzers, ${ }^{3,19,20}$ but such measurements are not performed routinely in China.

52 Another common approach involves thermodynamic equilibrium analyses between gas and

53 aerosol phase for semivolatile species, requiring composition measurements and a thermodynamic

54 model (e.g., E-AIM or ISORROPIA). ${ }^{2,21,22}$ Intercomparisons indicate that water contents estimated 
55 from the two approaches are in good agreement. ${ }^{3,12,23}$ Thermodynamic analyses on the basis of 56 gaseous and aerosol compositions are also considered as the best available method to estimate the $57 \mathrm{pH}$ of ambient aerosols. ${ }^{24}$ Direct $\mathrm{pH}$ measurement techniques developed in the laboratory are 58 difficult to apply in ambient air. ${ }^{25,26}$ Over the past few years, dozens of studies have examined the 59 water content and acidity of northern China winter haze aerosols using thermodynamic models. ${ }^{10-}$

$60 \quad 12,27-36$ Major findings include: aerosol water content, mainly contributed by uptake of inorganic 61 components, increases rapidly with haze accumulation due to enhancement of both particle mass 62 and $\mathrm{RH}$; and aqueous aerosols are moderately acidic (average $\mathrm{pH}$ of about 4 to 5) primarily due to 63 abundant ammonia.

64 Stringent anthropogenic emission controls, especially since implementation of the China 65 Clean Air Action Plan in 2013, have led to considerable changes in aerosol loadings and chemical 66 compositions as well as in the levels of reactive gases. ${ }^{37-42}$ For example, the annual mean 67 concentrations of fine particles decreased by about $50 \%$ over the North China Plain during 2013682018 , according to the national monitoring network. ${ }^{43}$ The question arises, but remains unanswered, 69 as to how the water content and acidity of aerosols have responded to these changes. Quantifying 70 their responses is helpful for evaluating potential feedbacks associated with secondary aerosol 71 production. Here, we conduct thermodynamic analyses using high-time-resolution data observed 72 in Beijing for four winter seasons from 2014/2015 to 2018/2019. To our knowledge, this is the 73 first attempt to address the questions highlighted here for this region, although the sensitivity of 74 aerosol acidity to changes in chemical compositions has been studied in other areas, e.g., North 75 America. ${ }^{44-49}$ 


\section{MATERIALS AND METHODS}

77 Field campaigns in four winter seasons (2014/2015, 2016/2017, 2017/2018, and 2018/2019) were conducted in urban Beijing. Meteorological variables (temperature and $\mathrm{RH}$ ), gaseous ammonia,

79 and chemical components of non-refractory submicron particles (NR-PM $)$ including organics,

80 sulfate, nitrate, ammonium, and chloride, were measured at time resolutions $<5$ minutes. Details

81 (sampling dates and location, instrumentation, and uncertainty quantification) are provided in the

82 Supporting Information (SI). Measured chemical species and meteorological parameters served as

83 inputs to the ISORROPIA II thermodynamic equilibrium model for calculating the water content

84 and $\mathrm{pH}$ of inorganic aerosols $\left(\mathrm{pH}_{\mathrm{i}}\right) .{ }^{21,50} \mathrm{Here}, \mathrm{pH}_{\mathrm{i}}$ was defined as the molality-based hydrogen ion

85 activity on a logarithmic scale, following the recommendation by the International Union of Pure

86 and Applied Chemistry (IUPAC), ${ }^{51}$

$$
\mathrm{pH}_{\mathrm{i}}=-\log _{10}\left(a_{\mathrm{H}_{(\mathrm{aq})}^{+}}\right)=-\log _{10}\left(m_{\mathrm{H}_{(\mathrm{aq})}^{+}} \gamma_{\mathrm{H}_{(\mathrm{aq})}^{+}} / m^{\Theta}\right)
$$

89 where $a_{\mathrm{H}_{(\mathrm{aq})}^{+}}$is hydrogen ion activity in aqueous solution, $\mathrm{H}_{(\mathrm{aq})}^{+} \cdot m_{\mathrm{H}_{(\mathrm{aq})}^{+}}$and $\gamma_{\mathrm{H}_{(\mathrm{aq})}^{+}}$are the molality

90 and the molality-based activity coefficient of $\mathrm{H}_{(\mathrm{aq})}^{+}$, respectively. $m^{\Theta}=1 \mathrm{~mol} \mathrm{~kg}^{-1}$ is the standard

91 molality. The model inputs were averaged on an hourly basis for consistency with the timescales

92 for semivolatile species to reach equilibrium. ${ }^{52}$ Only inorganic aerosol species (i.e., sulfate, nitrate,

93 ammonium, and chloride) were included in our calculations, since inorganics and organics were

94 expected to reside in separate liquid phases for Beijing winter haze. The average oxygen-to-carbon

$95(\mathrm{O} / \mathrm{C})$ elemental ratios were observed to $\mathrm{be}<0.5,{ }^{53}$ and studies have shown that liquid-liquid phase

96 separation of organic-inorganic mixtures occurs almost always when $\mathrm{O} / \mathrm{C}<0.5 .^{24,54,55}$ It should

97 be noted that hydrophilic organic acid salts (e.g., oxalate) may reside in the same phase with

98 inorganic ions, but unfortunately they were not measured in this study. We thus conducted a 
99 sensitivity calculation to evaluate the potential influence of their presence on the modeled acidity

100 and water uptake. Another drawback in our measurements was not including non-volatile cations,

101 and we conducted another sensitivity calculation to evaluate their possible effect.

102 The most recent ISORROPIA model v2.3 was used with the $\mathrm{pH}$ algorithmic issue fixed. ${ }^{33}$ The $103 \mathrm{pH}$ solution procedure has been described in Song et al. (2018). ${ }^{33}$ Because the amount of aerosol

104 water is much smaller than that of water vapor in the atmosphere, the model assumes that aerosol 105 water uptake does not change ambient RH. ${ }^{1}$ In addition, the model does not consider the effect of 106 surface tension on equilibrium droplet radii, which may be important for aerosols with radii less 107 than about $50 \mathrm{~nm} .{ }^{56}$ Given these assumptions, phase equilibrium shows that aerosol water activity $108\left(a_{w}\right)$ equals to RH. Aerosol water content (AWC) in ISORROPIA is estimated with the Zdanovskii109 Stokes-Robinson (ZSR) mixing rule, ${ }^{57,58}$ linking water uptake of a multicomponent aerosol to that 110 of the individual electrolytes,

$$
\mathrm{AWC}=\sum_{i} \frac{M_{i}}{m_{o i}\left(a_{w}\right)}
$$

113 where AWC is the total water concentration $\left(\mathrm{kg} \mathrm{m}^{-3}\right), M_{i}$ is the molar concentration of electrolyte $114 i\left(\mathrm{~mol} \mathrm{~m}^{-3}\right)$ and is solved iteratively in the model, and $m_{o i}\left(a_{w}\right)$ is the molality $\left(\mathrm{mol} \mathrm{kg}^{-1}\right)$ of a binary 115 solution of electrolyte $i$ at a given $a_{w} . m_{o i}\left(a_{w}\right)$ is specified in ISORROPIA using outputs from the 116 model E-AIM III. Although based on semi-ideality, the ZSR rule has been shown to provide a 117 good prediction of water uptake and widely used in aerosol models. ${ }^{59-62}$ The mass growth factor 118 for inorganic aerosols, $G_{\mathrm{mi}}$, was computed as Equation (3) using the $\mathrm{AWC}\left(\mathrm{kg} \mathrm{m}^{-3}\right)$ and dry aerosol 119 concentration $\left(m_{\mathrm{i}}, \mathrm{kg} \mathrm{m}^{-3}\right)$ calculated using the ISORROPIA model and measured chemical species 120 and meteorological parameters. 


$$
G_{\mathrm{mi}}=\frac{\mathrm{AWC}+m_{\mathrm{i}}}{m_{\mathrm{i}}}
$$

123 Here, we exported the contribution of each electrolyte to the total AWC from ISORROPIA,

124 in order to evaluate the effect of aerosol composition changes. The forward mode (using total 125 chemical measurements as inputs) was adopted in this work, since the reverse mode (using only 126 particle data as inputs) is strongly affected by errors in particle measurements. ${ }^{63}$ The calculations

127 were made assuming both stable and metastable thermodynamic equilibrium states, with the stable 128 assuming that solids precipitate when $\mathrm{RH}$ is below the deliquescence $\mathrm{RH}$ and the metastable 129 assuming that aerosols may constitute a supersaturated solution at low RH. We used a Monte Carlo 130 approach to propagate measurement uncertainties to model predictions (more information in SI). ${ }^{33}$

131 The measured and predicted gaseous $\mathrm{NH}_{3}$ concentrations agreed reasonably well, indicating good 132 model behavior (Figure S1).

133 Our thermodynamic model calculations were conducted mainly using ISORROPIA because 134 of its high computational efficiency (allowing for uncertainty quantification using the Monte Carlo 135 approach) and because of the availability of its source code (allowing for model development to 136 evaluate the relative contributions of different electrolytes to aerosol water uptake). But since it is 137 developed for large-scale atmospheric models, ISORROPIA is subject to many simplifications. ${ }^{21}$ 138 Thus, we also conducted thermodynamic calculations using a benchmark model E-AIM IV. ${ }^{64}$

\section{3. RESULTS AND DISCUSSION}

140 Figure 1 shows mass fractions of NR-PM1 chemical components for four winter seasons including 141 also a comparison of aerosol compositions under low and high RH conditions. A RH of $60 \%$ was 142 chosen as the dividing line since the particle physical state transitions from the semisolid to liquid 143 state when ambient RH increases above this value. ${ }^{14}$ Similar to previous studies, ${ }^{12,65,66}$ we found 
144 that the mass fractions of sulfate increased by $50 \%-130 \%$ at high $\mathrm{RH}$ compared with low RH 145 conditions, which had been hypothesized to arise from sulfate production in aerosol water through 146 different chemical pathways. ${ }^{10,11,67,68}$ Dissolved $\mathrm{SO}_{2}$ (aq) (the sum of $\mathrm{SO}_{2} \cdot \mathrm{H}_{2} \mathrm{O}, \mathrm{HSO}_{3}{ }^{-}$, and $\mathrm{SO}_{3}{ }^{2-}$ )

147 has been suggested to be oxidized in aerosol water by $\mathrm{NO}_{2}, \mathrm{H}_{2} \mathrm{O}_{2}$, and $\mathrm{O}_{2}$ catalyzed by transition 148 metal ions $\left(\mathrm{Fe}^{3+}\right.$ and $\left.\mathrm{Mn}^{2+}\right)$. The higher $\mathrm{RH}$ resulted in an increase in aerosol water content, which 149 provided a larger volume for heterogeneous reactions to occur. From 2014/2015 to 2018/2019, the 150 mass fractions of nitrate increased by a factor of about 1.5. Nitrate has replaced sulfate as the most 151 abundant inorganic component, ${ }^{40}$ a circumstance that may be attributed to the faster decline of 152 emissions of $\mathrm{SO}_{2}$ relative to $\mathrm{NO}_{x}$ in Beijing and surrounding areas. ${ }^{38,43}$ The mass fractions of 153 organics and chloride were reduced, likely due to the substantial decreases in coal and biomass 154 combustions. ${ }^{38,42,53,69}$

155 Figure 1 also shows that the mass concentrations of $\mathrm{PM}_{1}$ varied significantly among different 156 winters. The average $\mathrm{PM}_{1}$ concentrations in $2017 / 2018$ winter $\left(46 \mu \mathrm{g} \mathrm{m}^{-3}\right.$ at high $\left.\mathrm{RH}\right)$ were much 157 lower compared with the other winter seasons (from 139 to $222 \mu \mathrm{g} \mathrm{m}^{-3}$ at high $\mathrm{RH}$ ). Several studies 158 (using chemical transport models or statistical models) have investigated the influences of reduced 159 emissions and meteorology on PM concentrations in Beijing for recent years. ${ }^{43,70,71}$ They generally 160 suggested a major role of emission and a minor role of meteorology. Cheng N. et al. (2019) ${ }^{70}$ found, 161 different from the other seasons, that wintertime $\mathrm{PM}_{2.5}$ did not decrease significantly (on a $90 \%$ 162 confidence level) during 2013-2016 due to unfavorable meteorological conditions. Cheng J. et al. $163(2019)^{71}$ showed that $\mathrm{PM}_{2.5}$ mass concentrations in 2017/2018 winter would increase by about $80 \%$ 164 if the meteorological conditions were the same with 2016/2017 winter, although there was a 165 negative bias in the modeled $\mathrm{PM}_{2.5}$ compared to observations in 2016/2017. More stringent 166 emission control measures, including the suspension of industrial activities and the replacement of 
167 coal with natural gas, were implemented in 2017/2018 winter over Beijing and surrounding regions 168 in order to meet the target of $\mathrm{PM}_{2.5}$ concentration for the 2013-2017 Clean Air Action Plan, and

169 were suggested to significantly reduce PM concentrations during this winter season. ${ }^{72}$ In this study,

$170 G_{\mathrm{mi}}$ was used to evaluate the response of inorganic aerosol water uptake to the changes in the mass

171 fractions of aerosol components. It was considered a better metric for such a purpose than AWC

172 since it was primarily affected by mass fractions of chemical species rather than aerosol dry mass, 173 which varied among different haze events as described above.

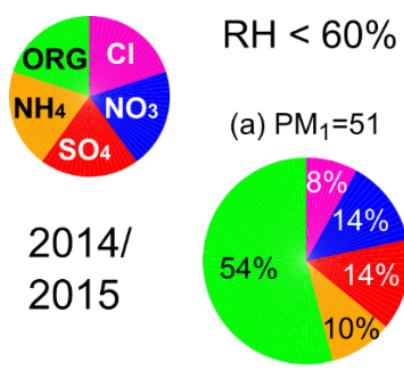

(c) $\mathrm{PM}_{1}=70$

2016/

2017

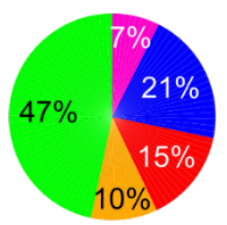

(e) $\mathrm{PM}_{1}=18$

2017/

2018

175

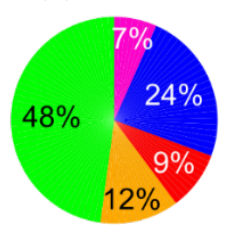

(g) $\mathrm{PM}_{1}=30$

2018/

2019

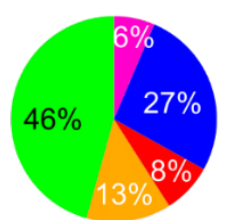

(b) $\mathrm{PM}_{1}=139$

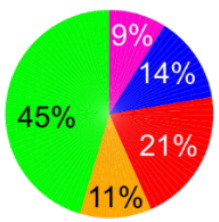

(d) $\mathrm{PM}_{1}=222$

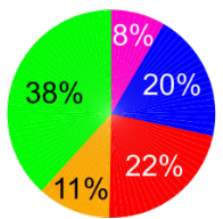

(f) $\mathrm{PM}_{1}=46$

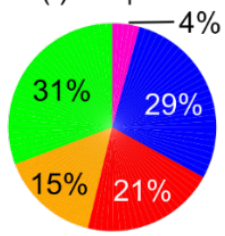

(h) $\mathrm{PM}_{1}=152$

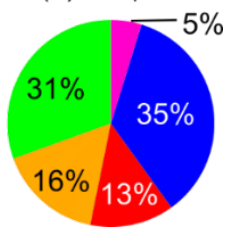

176 Figure 1. Mean mass fractions of NR-PM1 chemical components at low $(<60 \%)$ and high $(>60 \%)$

177 RH conditions. (a-b), (c-d), (e-f), and (g-h) present data for the winters of 2014/2015, 2016/2017, 


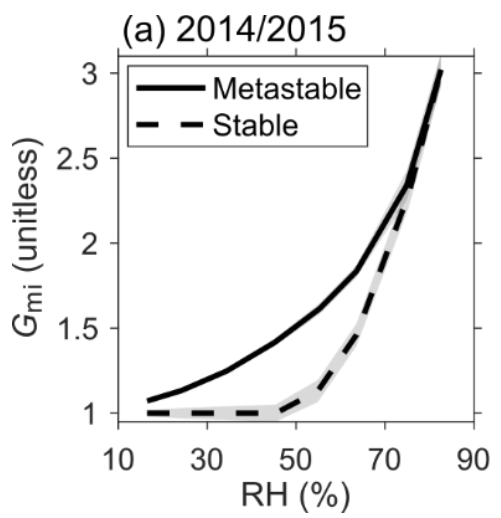

91

2017/2018, and 2018/2019, respectively. The unit of $\mathrm{PM}_{1}$ concentration is $\mu \mathrm{g} \mathrm{m}^{-3}$. ORG, $\mathrm{NH}_{4}$, $\mathrm{SO}_{4}, \mathrm{NO}_{3}$, and $\mathrm{Cl}$ represent organics, ammonium, sulfate, nitrate, and chloride, respectively.

Figure 2(a) shows the modeled $G_{\mathrm{mi}}$ in winter 2014/2015 as a function of RH. Ambient aerosols could exist in either stable or metastable equilibrium state, depending on their compositions and $\mathrm{RH}$ experience, ${ }^{73}$ but there has not been enough evidence to demonstrate the state of Beijing winter aerosols. ${ }^{33}$ As we expect, $G_{\mathrm{mi}}$ increased from 1.0 to about 3.0 when $\mathrm{RH}$ increased from $17 \%$ to $83 \%$. The metastable $G_{\mathrm{mi}}$ showed a monotonic increase with $\mathrm{RH}$, while the stable $G_{\mathrm{mi}}$ remained at 1.0 below $\mathrm{RH}$ of about $50 \%$ (the mutual deliquescence $\mathrm{RH}$ ). $G_{\mathrm{mi}}$ in both states converged when $\mathrm{RH}$ reached $75 \%$ as all inorganic salts deliquesced. As shown in Figure $2(\mathrm{~b}-\mathrm{c})$, the modeled $G_{\mathrm{mi}}$ in the following winter seasons decreased relative to 2014/2015, regardless of state assumptions. The amplitudes for $G_{\mathrm{mi}}$ decline increased with $\mathrm{RH}$, reaching $3 \% \pm 3 \%, 10 \% \pm 3 \%$, and $13 \% \pm 4 \%$ in $2016 / 2017,2017 / 2018$, and 2018/2019, respectively.

193 Figure 2. (a) shows inorganic aerosol mass growth factors $\left(G_{\mathrm{mi}}\right)$ for the $2014 / 2015$ winter as a

194 function of RH modeled using both metastable and stable assumptions. (b-c) show the relative $G_{\mathrm{mi}}$ 195 changes in the winters of 2016/2017, 2017/2018 and 2018/2019 as compared to 2014/2015. Data 196 are grouped in RH bins (10\% increment). The shaded areas indicate the $1 \sigma$ uncertainty range. 
We show next that the modeled declining water-uptake ability resulted from changed 199 inorganic aerosol compositions. Figure 3(a-c) present the contribution of each electrolyte $200\left(\left(\mathrm{NH}_{4}\right)_{2} \mathrm{SO}_{4}, \mathrm{NH}_{4} \mathrm{NO}_{3}\right.$, and $\left.\mathrm{NH}_{4} \mathrm{Cl}\right)$ to the total AWC. Note that the AWC calculation followed the 201 ZSR rule and that almost all sulfate existed in the form of $\left(\mathrm{NH}_{4}\right)_{2} \mathrm{SO}_{4}$. Figure 3(d) shows the 202 amount of water uptake per electrolyte on a mass basis. Note that $\left(\mathrm{NH}_{4}\right)_{2} \mathrm{SO}_{4}$ and $\mathrm{NH}_{4} \mathrm{Cl}$ are subject 203 to efflorescence at $\mathrm{RH}$ of above $30 \%$ and extending the curves to lower $\mathrm{RH}$ may not be realistic 204 for these pure salts. ${ }^{74}$ Ambient particles consisting of multiple salts exhibit a more complex 205 behavior in efflorescence RH. The curves in Figure 3(d) are thus used only to demonstrate the 206 different water-uptake ability of each electrolyte. Among the three electrolytes, $\left(\mathrm{NH}_{4}\right)_{2} \mathrm{SO}_{4}$ showed 207 the highest ability and $\mathrm{NH}_{4} \mathrm{NO}_{3}$ the lowest. We found, below 30\% $\mathrm{RH}$, that most water uptake 208 could be attributed to $\left(\mathrm{NH}_{4}\right)_{2} \mathrm{SO}_{4}$. At high $\mathrm{RH}$, all three electrolytes contributed significantly. The 209 importance of $\mathrm{NH}_{4} \mathrm{Cl}$ has often been ignored in previous studies. The contribution of $\mathrm{NH}_{4} \mathrm{NO}_{3}$ 210 increased from $<20 \%$ in $2014 / 2015$ to $>50 \%$ in $2018 / 2019$, whereas the contributions of both $211\left(\mathrm{NH}_{4}\right)_{2} \mathrm{SO}_{4}$ and $\mathrm{NH}_{4} \mathrm{Cl}$ decreased over the same period. During recent years, the relative increase 212 and low water-uptake ability of $\mathrm{NH}_{4} \mathrm{NO}_{3}$ have resulted in a $9 \%-17 \%$ decline of the modeled $G_{\mathrm{mi}}$ 213 during winter haze events (Figure 2). As mentioned in METHODS, ISORROPIA uses the output 214 data from E-AIM model III $^{75}$ to specify the amount of water uptake for each electrolyte. It should 215 be noted that for $\mathrm{NH}_{4} \mathrm{NO}_{3}$ and $\left(\mathrm{NH}_{4}\right)_{2} \mathrm{SO}_{4}$ the water-uptake data in E-AIM III are different from 216 those in E-AIM model $\mathrm{II}^{76}$ and $\mathrm{IV}^{64}$ (these two versions have very similar data) when RH is below 217 about 50\% (Figure S2). A recalculation using the water-uptake data from E-AIM IV shows, when $218 \mathrm{RH}$ is below $50 \%$, a higher contribution of $\mathrm{NH}_{4} \mathrm{NO}_{3}$ and a lower contribution of $\left(\mathrm{NH}_{4}\right)_{2} \mathrm{SO}_{4}$ to the 219 total AWC (Figure S3). As this study was focused on winter haze conditions associated with high 

main findings.

(a) Ammonium Sulfate

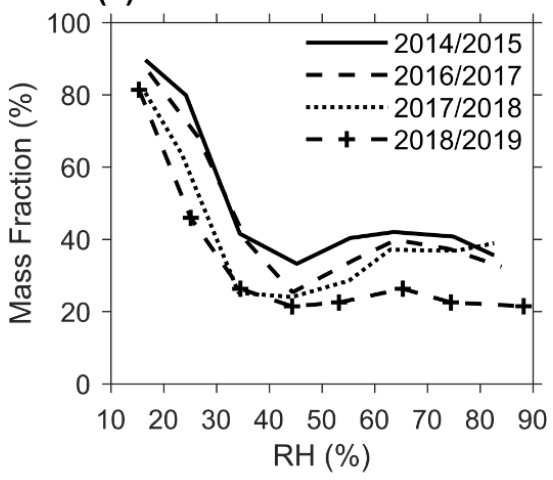

(c) Ammonium Chloride

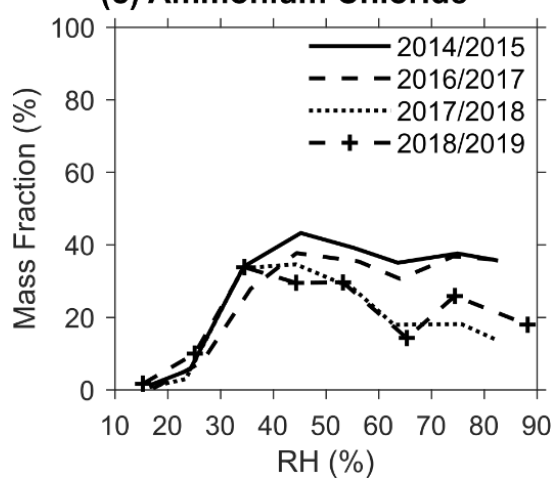

(b) Ammonium Nitrate

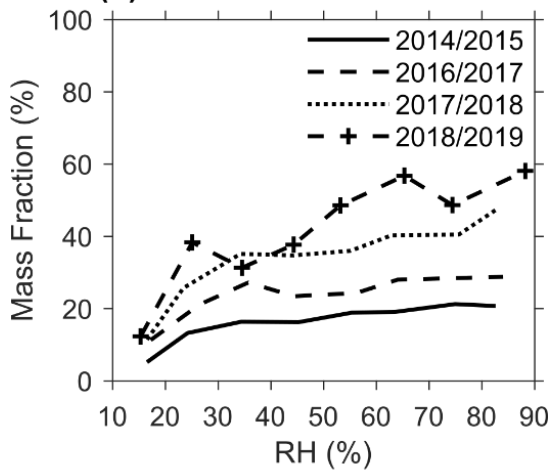

(d)

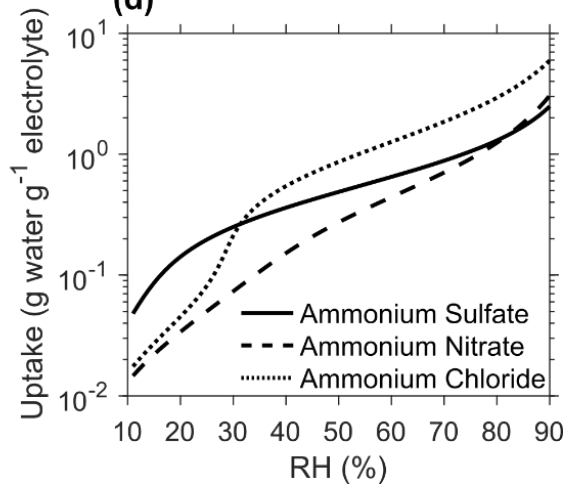

224 Figure 3. (a-c) show the modeled mass fractions of aerosol water content associated with different

225 electrolytes. (d) shows the amount of water uptake per mass of each electrolyte in a binary solution.

226 Data are presented as a function of RH. Data in $(a-c)$ are calculated based on field measurements

227 and ISORROPIA and grouped in RH bins (10\% increment). Data in (d) are obtained from ISORROPIA.

$\mathrm{pH}_{\mathrm{i}}$ of Beijing haze aerosols has been suggested to be buffered by abundant ammonia in the 231 gas phase. ${ }^{32-34}$ Under such condition, the partitioning of nitric acid $\left(\mathrm{HNO}_{3(\mathrm{~g})} \leftrightarrow \mathrm{H}_{(\mathrm{aq})}^{+}+\mathrm{NO}_{3(\mathrm{aq})}^{-}\right)$

232 and hydrochloric acid $\left(\mathrm{HCl}_{(\mathrm{g})} \leftrightarrow \mathrm{H}_{(\mathrm{aq})}^{+}+\mathrm{Cl}_{(\mathrm{aq})}^{-}\right)$was strongly shifted toward the aerosol phase, 
233 and thus both $\left[\mathrm{HNO}_{3(\mathrm{~g})}\right]$ and $\left[\mathrm{HCl}_{(\mathrm{g})}\right]$ were very low, ${ }^{32,33}$ suggesting that they did not strongly

234 buffer $\mathrm{pH}_{\mathrm{i}}$. We derive the buffer equation from phase equilibrium of $\mathrm{NH}_{3(\mathrm{~g})}+\mathrm{H}_{(\mathrm{aq})}^{+} \leftrightarrow \mathrm{NH}_{4(\mathrm{aq})}^{+}$

235 (details in the SI), similar to the Henderson-Hasselbalch equation, ${ }^{77}$

$$
\mathrm{pH}_{\mathrm{i}}=\mathrm{p} K^{*}+\log _{10}\left(\frac{\left[\mathrm{NH}_{3(\mathrm{~g})}\right]}{a_{\mathrm{NH}_{4(\mathrm{aq})}^{+}}}\right)
$$

238 where $K^{*}\left(\mu \mathrm{mol} \mathrm{m}{ }^{-3}\right)$ is the apparent equilibrium constant, $\left[\mathrm{NH}_{3(\mathrm{~g})}\right]\left(\mu \mathrm{mol} \mathrm{m}{ }^{-3}\right)$ is gaseous $\mathrm{NH}_{3}$ 239 molar concentration, and $a_{\mathrm{NH}_{4(\mathrm{aq})}^{+}}\left(\mathrm{mol} \mathrm{kg}^{-1}\right)=\left[\mathrm{NH}_{4(\mathrm{aq})}^{+}\right] \gamma_{\mathrm{NH}_{4(\mathrm{aq})}^{+}}$is the molality-based activity of $240 \mathrm{NH}_{4(\mathrm{aq})}^{+}$. Equation (4) suggests that $\mathrm{pH}_{\mathrm{i}}$ is affected by three variables: $\mathrm{p} K^{*},\left[\mathrm{NH}_{3(\mathrm{~g})}\right]$, and $a_{\mathrm{NH}_{4(\mathrm{aq})}^{+}}$.

$241 \mathrm{p} K^{*}$ depends only on $T$ and decreases by about 0.05 unit per $\mathrm{K}$ increase. This dependence reflects

242 the relationships of both ammonia solubility and water dissociation with $T \cdot \log _{10}\left(\left[\mathrm{NH}_{3(\mathrm{~g})}\right]\right)$

243 indicates about a 1 unit increase in $\mathrm{pH}_{\mathrm{i}}$ per 10 -fold increase in $\left[\mathrm{NH}_{3(\mathrm{~g})}\right]$, consistent with earlier

244 results from Guo et al. (2017). ${ }^{34}$ The buffering capacity of the gas-aerosol system, defined as the 245 amount of acidic or basic species necessary to change $\mathrm{pH}_{\mathrm{i}}$ by 1 unit, increases with $\left[\mathrm{NH}_{3(\mathrm{~g})}\right]$

$246\left(\partial \mathrm{pH}_{\mathrm{i}} / \partial\left[\mathrm{NH}_{3(\mathrm{~g})}\right] \approx 0.4 /\left[\mathrm{NH}_{3(\mathrm{~g})}\right]\right) \cdot a_{\mathrm{NH}_{4(\mathrm{aq})}^{+}}$is a function of $\mathrm{RH}$ and is also affected by aerosol

247 composition (ions coexisting in the aqueous phase). We show, in the SI, that the sensitivities of $248 \mathrm{pH}$ i to these variables are consistent between Equation (4) and thermodynamic models. This simple 249 buffer equation can help understand the influence of different meteorological and chemical factors 250 on the $\mathrm{pH}_{\mathrm{i}}$ estimated by thermodynamic modeling.

251 As shown in Figure 4, the mean ( \pm standard error) $\mathrm{pH}_{\mathrm{i}}$ modeled by ISORROPIA were $4.52 \pm$ $2520.02,4.73 \pm 0.05,4.77 \pm 0.03$, and $4.89 \pm 0.04$ for the winters of $2014 / 2015,2016 / 2017,2017 / 2018$, 253 and 2018/2019, respectively. The differences between 2014/2015 and 2016/2017 and between 
$2542017 / 2018$ and 2018/2019 were statistically significant ( $p<0.05$ from the Mann-Whitney $U$ test),

255 whereas that between 2016/2017 and 2017/2018 was insignificant. Note that only data for RH > $25660 \%$ were considered when $\mathrm{PM}_{1}$ was liquid. The bias in $\mathrm{pH} \mathrm{H}_{\mathrm{i}}$ owing to the $T$ difference was removed.

257 An increase of $0.37 \pm 0.05$ unit from 2014/2015 to 2018/2019 was estimated in the modeled $\mathrm{pH}_{\mathrm{i}}$

258 by ISORROPIA, agreeing well with the $\mathrm{pH}$ increase of about 0.4 unit modeled by E-AIM (Figure

259 4b). Although both models suggested a similar increase in $\mathrm{pH}_{\mathrm{i}}$, a systematic difference existed in

260 their modeled $\mathrm{pH}$, probably arising from different treatments of hydrogen ion activity coefficient

$261 \quad\left(\gamma_{\mathrm{H}_{(\mathrm{aq})}^{+}}\right)$and bisulfate ion dissociation. ${ }^{33,78}$

262 The modeled $\mathrm{pH}_{\mathrm{i}}$ increases of $0.3-0.4$ unit from $2014 / 2015$ to $2018 / 2019$ could be explained

263 by changes in $\left[\mathrm{NH}_{3(\mathrm{~g})}\right]$ and $a_{\mathrm{NH}_{4(\mathrm{aq})}^{+}} \cdot \log _{10}\left(\left[\mathrm{NH}_{3(\mathrm{~g})}\right]\right)$ increased by about 0.3 during this time

264 period. The changes in aerosol composition (more nitrate and less sulfate and chloride) led to a

265 minor decrease in $\gamma_{\mathrm{NH}_{4(\text { aq }}^{+}}$and thus increased $\mathrm{pH}_{\mathrm{i}}$ by about 0.1 unit (Figure $\mathrm{S6}$ ). It was noted that

266 our thermodynamic calculations used the total (gas + aerosol) measurements of semivolatile

267 species as inputs and allowed them to be repartitioned between the two phases. If aerosol

268 measurements of chemical species were not charge balanced, which was common given the

269 various uncertainties in sampling and chemical analyses, the modeled and measured $\left[\mathrm{NH}_{3(\mathrm{~g})}\right]$

270 might differ due to its repartitioning (for achieving the charge balance in the modeled aerosol

271 phase), introducing an additional bias in the modeled $\mathrm{pH}_{\mathrm{i}}$. The largest disagreement occurred in

$2722014 / 2015$ winter when ISORROPIA underpredicted $\left[\mathrm{NH}_{3(\mathrm{~g})}\right]$ by about $20 \%$ compared with the

273 measurements (Figure S1). A sensitivity calculation showed that the disagreement in 2014/2015

274 implied a possible bias in the modeled $\mathrm{pHi}$ by about 0.1 unit. 
(a)

276

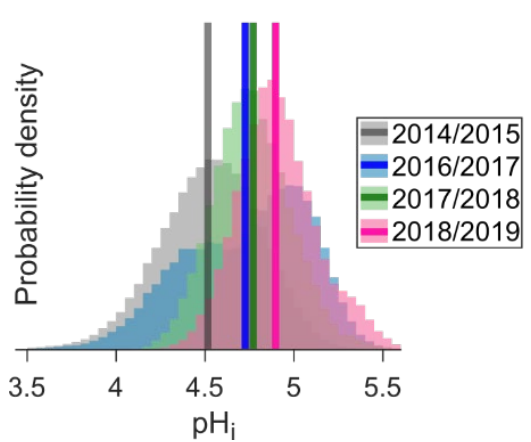

(b)

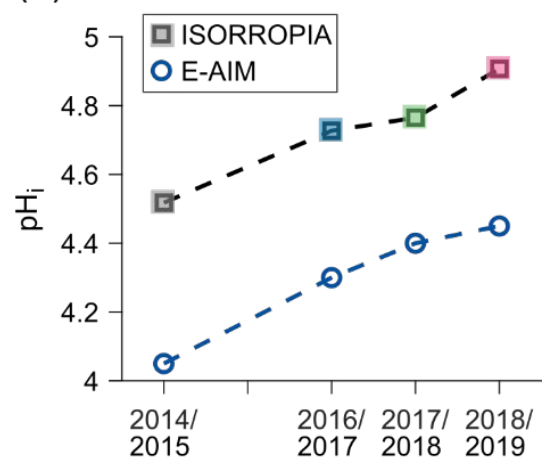

277 Figure 4. (a) shows the mean values and probability density distributions of aerosol $\mathrm{pH}$ modeled

278 by ISORROPIA in recent winters. (b) presents the mean $\mathrm{pH}_{\mathrm{i}}$ calculated from both ISORROPIA

279 and E-AIM. Data were obtained under high RH condition (> 60\%).

In summary, this study provides two new findings for Beijing winter haze events which are associated with high RH. First, the water-uptake ability of inorganic aerosols, characterized by the

283 modeled $G_{\mathrm{mi}}$, declined by about $9 \%-17 \%$ during the four seasons (from $2014 / 2015$ to $2018 / 2019$ )

284 due to changes in aerosol chemical composition. Nitrate has become the primary species to uptake 285 aerosol water. Second, inorganic aerosol acidity, characterized by the modeled $\mathrm{pH}_{\mathrm{i}}$ which 286 increased by about $0.3-0.4$ unit during this time period, also declined mainly as a response to rising 287 ammonia. There are several limitations and assumptions in this work. First, the thermodynamic 288 calculations conducted here assumed internally mixed inorganic aerosols and phase equilibrium.

289 Second, the acidity of organic aerosol phase was not investigated. ${ }^{79}$ The water content associated 290 with organics estimated by the $\kappa$-Köhler theory ${ }^{80}$ was about a factor of 5 lower than that with 291 inorganics in Beijing winter haze. ${ }^{33}$ Third, minor water-soluble aerosol species, primarily 292 including nonvolatile cations and hydrophilic organic acid salts, were unavailable in our 293 measurements. Accordingly, two sensitivity calculations were conducted (details in the SI) using 294 the available data measured under Beijing winter haze conditions by previous studies, and their 
results suggested that the finding of declined acidity and water uptake remained when considering 296 nonvolatile cations and hydrophilic organic acids.

297 The findings of this study have two implications. First, there are either positive or negative 298 chemical feedbacks in secondary aerosol production. On one hand, the declining aerosol water 299 uptake implies that the volume for heterogenous processes to occur has become smaller during 300 recent winter seasons. On the other hand, heterogeneous chemical reactions may be enhanced or 301 inhibited by declining aerosol acidity (i.e., rising aerosol $\mathrm{pH}$ ). ${ }^{9}$ Examples include nitrate photolysis 302 and subsequent $\mathrm{HONO} / \mathrm{NO}_{2}{ }^{-}$production, ${ }^{81}$ organosulfates (OSs) and nitrooxy-Oss formation, ${ }^{82,83}$ 303 and the oxidation of $\mathrm{SO}_{2}$ (aq) (the sum of $\mathrm{SO}_{2} \cdot \mathrm{H}_{2} \mathrm{O}, \mathrm{HSO}_{3}{ }^{-}$, and $\mathrm{SO}_{3}{ }^{2-}$ ) by $\mathrm{NO}_{2}, \mathrm{O}_{3}$, and transition 304 metals $+\mathrm{O}_{2} \cdot{ }^{10}$ The increase of 0.3 unit in the modeled $\mathrm{pH}$ from 2014/2015 to 2018/2019 winter 305 translated to a halved $a_{\mathrm{H}_{(\mathrm{aq})}^{+}}$. A calculation following Shao et al. (2019) ${ }^{18}$ suggested that these two 306 factors together could have led to large increases in the in-situ oxidation rates of $\mathrm{SO}_{2}$ (aq) by $\mathrm{O}_{3}$ $307(+240 \%)$ and $\mathrm{NO}_{2}(+70 \%)$ whereas a significant decrease in the oxidation rate by transition metals $308+\mathrm{O}_{2}(-90 \%)$. Note in this calculation that the other factors (e.g., the reactant concentrations in the 309 aqueous phase) were assumed to remain the same in order to isolate the effects of aerosol water 310 uptake and acidity. The $\mathrm{O}_{3}$ and $\mathrm{NO}_{2}$ pathways responded positively to $\mathrm{pH}$ because the solubility 311 of $\mathrm{SO}_{2(\mathrm{aq})}$ increased at higher $\mathrm{pH}$ and because the equilibrium among $\mathrm{SO}_{2} \cdot \mathrm{H}_{2} \mathrm{O}, \mathrm{HSO}_{3}{ }^{-}$, and $\mathrm{SO}_{3}{ }^{2-}$ 312 shifted with changed $\mathrm{pH} .{ }^{74}$ The change in the $\mathrm{O}_{3}$ reaction pathway than the $\mathrm{NO}_{2}$ pathway since $\mathrm{O}_{3}$ 313 mainly reacted with $\mathrm{SO}_{3}{ }^{2-}$ while $\mathrm{NO}_{2}$ reacted with $\mathrm{HSO}_{3}{ }^{-10} \cdot{ }^{10}$ The negative response of the transition 314 metals $+\mathrm{O}_{2}$ pathway arose partly from the high solubility of $\mathrm{Fe}^{3+}$ and $\mathrm{Mn}^{2+}$ at low $\mathrm{pH} .{ }^{18} \mathrm{Chemical}$ 315 feedbacks may help explain the observed slower declines in sulfate relative to $\mathrm{SO}_{2}$ for winter haze 316 during recent years. The sulfate/ $\mathrm{SO}_{2}$ ratios in $2018 / 2019$ increased by about $80 \%$ compared to the 317 ratios in 2014/2015 and by over a factor of 2 when compared to 2011/2012 (data from ref ${ }^{66}$ ) (Figure 
318 S7). Since almost all the sulfate is converted by $\mathrm{SO}_{2},{ }^{11}$ the enhanced sulfate $/ \mathrm{SO}_{2}$ ratios imply that

319 the oxidation of $\mathrm{SO}_{2}$ may have become more efficient. As shown earlier, the rates of $\mathrm{SO}_{2}$ oxidation

320 in aerosol water by $\mathrm{O}_{3}$ and $\mathrm{NO}_{2}$ increased as a result of declined aerosol acidity. Chemical transport

321 modeling studies should be conducted to investigate the contributions of different $\mathrm{SO}_{2}$ oxidation

322 pathways and the role of meteorology. A better characterization of the mechanisms responsible for

$323 \mathrm{SO}_{2}$ oxidation can help evaluate the effects of the past (and future) emission mitigation efforts.

324 The second implication is that reducing $\mathrm{NH}_{3}$ emissions may have become less effective than

325 before as a measure to alleviate Beijing winter haze pollution. ${ }^{84}$ The buffering capacity of the gas-

326 particle system have increased due to rising $\mathrm{NH}_{3}$. It should be noted that $\mathrm{NH}_{3}$ emissions in North

327 China, especially in urban areas, remain poorly quantified and the contributions of different

328 sources are subject to debate. Some studies ${ }^{85-89}$ have argued that slip of $\mathrm{NH}_{3}$ (due to urea used in

329 the selective catalytic reduction (SCR) systems) from industrial or power generation plants and

330 evasion from green space are important or even dominant sources to atmospheric $\mathrm{NH}_{3}$ in urban

331 areas. Fossil fuel combustion and biomass burning were also suggested to be potential sources. ${ }^{90,91}$

332 Others ${ }^{92-94}$ have argued that $\mathrm{NH}_{3}$ is dominated by agricultural activities (due to volatilization from

333 fertilizer and livestock waste). An additional factor hindering our understanding is that the current

334 estimates of agricultural $\mathrm{NH}_{3}$ emissions in China may differ by a factor of $2 .{ }^{94}$ The reason for

335 rising $\mathrm{NH}_{3}$ has also been poorly investigated. Liu et al. (2018) ${ }^{39}$ studied satellite observations of

$336 \mathrm{NH}_{3}$ columns and concluded that more rapid reductions in emissions of $\mathrm{SO}_{2}$ and $\mathrm{NO}_{x}$ compared to

$337 \mathrm{NH}_{3}$ led to an increase in tropospheric $\mathrm{NH}_{3}$ columns over the North China Plain since 2013. The

338 Multi-resolution Emission Inventory for China ${ }^{38}$ showed, during 2013-2017, that emissions of

$339 \mathrm{SO}_{2}, \mathrm{NO}_{x}$, and $\mathrm{NH}_{3}$ decreased by $65 \%, 20 \%$, and $4 \%$, respectively. Note that a few non-agricultural

340 sources of $\mathrm{NH}_{3}$ (e.g., slip) were not included in the inventory. The increasing penetration rates of 
341 SCR systems in power plants (50\% in 2013 and $95 \%$ in 2017$)^{38,95}$ may imply an increase in $\mathrm{NH}_{3}$

342 slip. Therefore, future research efforts need to be undertaken to quantify $\mathrm{NH}_{3}$ sources and driving

343 factors. From the perspective of thermodynamics and based on gas/aerosol measurement data, this

344 study suggests that a substantial $(>50 \%) \mathrm{NH}_{3}$ emission reduction is necessary to effectively reduce

345 inorganic aerosol mass under the present Beijing winter haze conditions.

\section{ASSOCIATED CONTENT}

\section{Supporting Information}

348 The Supporting Information is available free of charge on the ACS Publications website at DOI:

$34900.0000 /$ acs.000.0000000. Additional data, figures, and tables, some of which are referenced

350 directly within the manuscript. Also included are detailed descriptions of field measurements and

351 derivations of the buffer equation.

\section{AUTHOR INFORMATION}

\section{Corresponding Author}

354 S.W. (E-mail: shxwang@tsinghua.edu.cn), Y.S. (E-mail: sunyele@mail.iap.ac.cn), and B.L. (E355 mail: liubaoxian28@163.com)

356 Notes

357 The authors declare no competing financial interest.

\section{ACKNOWLEDGMENTS}

359 This publication was made possible by funding from the Harvard Global Institute and the National

360 Natural Science Foundation of China (21625701 and 91744207). We thank Simon Clegg for 361 helpful discussions on the E-AIM model. 


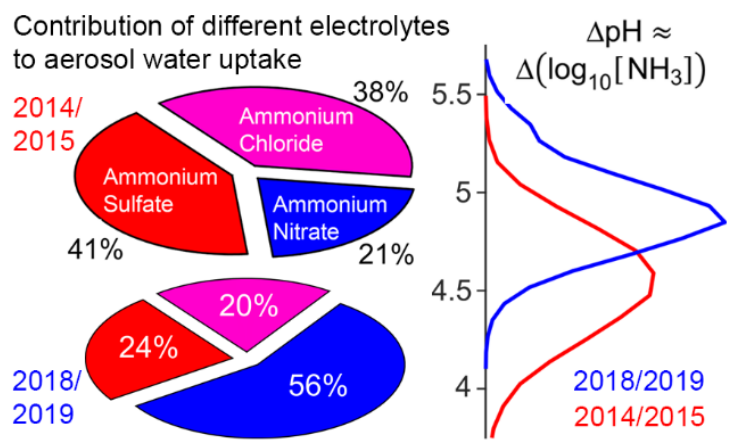

TOC Art

\section{REFERENCES}

(1) Nguyen, T. K. V.; Zhang, Q.; Jimenez, J. L.; Pike, M.; Carlton, A. G. Liquid water: ubiquitous contributor to aerosol mass. Environ. Sci. Technol. Lett. 2016, 3, 257-263.

(2) Pilinis, C.; Seinfeld, J. H.; Grosjean, D. Water content of atmospheric aerosols. Atmos. Environ. 1989, 23, 1601-1606.

(3) Guo, H.; Xu, L.; Bougiatioti, A.; Cerully, K. M.; Capps, S. L.; Hite Jr, J. R.; Carlton, A. G.; Lee, S. H.; Bergin, M. H.; Ng, N. L.; Nenes, A.; Weber, R. J. Fine-particle water and pH in the southeastern United States. Atmos. Chem. Phys. 2015, 15, 5211-5228.

(4) Malm, W. C.; Day, D. E. Estimates of aerosol species scattering characteristics as a function of relative humidity. Atmos. Environ. 2001, 35, 2845-2860.

(5) Martin, S. T.; Hung, H. M.; Park, R. J.; Jacob, D. J.; Spurr, R. J. D.; Chance, K. V.; Chin, M. Effects of the physical state of tropospheric ammonium-sulfate-nitrate particles on global aerosol direct radiative forcing. Atmos. Chem. Phys. 2004, 4, 183-214.

(6) Nah, T.; Guo, H.; Sullivan, A. P.; Chen, Y.; Tanner, D. J.; Nenes, A.; Russell, A.; Ng, N. L.; Huey, L. G.; Weber, R. J. Characterization of aerosol composition, aerosol acidity, and organic acid partitioning at an agriculturally intensive rural southeastern US site. Atmos. Chem. Phys. 2018, 18, 11471-11491.

(7) Alexander, B.; Park, R. J.; Jacob, D. J.; Li, Q. B.; Yantosca, R. M.; Savarino, J.; Lee, C. C. W.; Thiemens, M. H. Sulfate formation in sea-salt aerosols: Constraints from oxygen isotopes. J. Geophys. Res. Atmos. 2005, 110.

(8) Thornton, J. A.; Braban, C. F.; Abbatt, J. P. D. $\mathrm{N}_{2} \mathrm{O}_{5}$ hydrolysis on sub-micron organic aerosols: the effect of relative humidity, particle phase, and particle size. Phys. Chem. Chem. Phys. 2003, 5, 45934603.

(9) Ravishankara, A. R. Heterogeneous and multiphase chemistry in the troposphere. Science 1997, 276, 1058-1065.

(10) Cheng, Y.; Zheng, G.; Wei, C.; Mu, Q.; Zheng, B.; Wang, Z.; Gao, M.; Zhang, Q.; He, K.; Carmichael, G.; Pöschl, U.; Su, H. Reactive nitrogen chemistry in aerosol water as a source of sulfate during haze events in China. Sci. Adv. 2016, 2, e1601530.

(11) Wang, G.; Zhang, R.; Gomez, M. E.; Yang, L.; Levy Zamora, M.; Hu, M.; Lin, Y.; Peng, J.; Guo, S.; Meng, J.; Li, J.; Cheng, C.; Hu, T.; Ren, Y.; Wang, Y.; Gao, J.; Cao, J.; An, Z.; Zhou, W.; Li, G.; Wang, J.; Tian, P.; Marrero-Ortiz, W.; Secrest, J.; Du, Z.; Zheng, J.; Shang, D.; Zeng, L.; Shao, M.; Wang, W.; Huang, Y.; Wang, Y.; Zhu, Y.; Li, Y.; Hu, J.; Pan, B.; Cai, L.; Cheng, Y.; Ji, Y.; Zhang, F.; Rosenfeld, D.; Liss, P. S.; Duce, R. A.; Kolb, C. E.; Molina, M. J. Persistent sulfate formation from London Fog to Chinese haze. Proc. Natl. Acad. Sci. U. S. A. 2016, 113, 13630-13635.

(12) Wu, Z.; Wang, Y.; Tan, T.; Zhu, Y.; Li, M.; Shang, D.; Wang, H.; Lu, K.; Guo, S.; Zeng, L.; Zhang, Y. Aerosol liquid water driven by anthropogenic inorganic salts: Implying its key role in haze formation over the North China Plain. Environ. Sci. Technol. Lett. 2018, 5, 160-166. 
(13) Gao, J.; Woodward, A.; Vardoulakis, S.; Kovats, S.; Wilkinson, P.; Li, L.; Xu, L.; Li, J.; Yang, J.; Li, J.; Cao, L.; Liu, X.; Wu, H.; Liu, Q. Haze, public health and mitigation measures in China: A review of the current evidence for further policy response. Sci. Total Environ. 2017, 578, 148-157.

(14) Liu, Y.; Wu, Z.; Wang, Y.; Xiao, Y.; Gu, F.; Zheng, J.; Tan, T.; Shang, D.; Wu, Y.; Zeng, L.; Hu, M.; Bateman, A. P.; Martin, S. T. Submicrometer particles are in the liquid state during heavy haze episodes in the urban atmosphere of Beijing, China. Environ. Sci. Technol. Lett. 2017, 4, 427-432.

(15) Gen, M.; Zhang, R.; Huang, D. D.; Li, Y.; Chan, C. K. Heterogeneous $\mathrm{SO}_{2}$ oxidation in sulfate formation by photolysis of particulate nitrate. Environ. Sci. Technol. Lett. 2019, 6, 86-91.

(16) Hung, H.-M.; Hsu, M.-N.; Hoffmann, M. R. Quantification of $\mathrm{SO}_{2}$ oxidation on interfacial surfaces of acidic micro-droplets: Implication for ambient sulfate formation. Environ. Sci. Technol. 2018, 52, 9079-9086.

(17) Li, L.; Hoffmann, M. R.; Colussi, A. J. Role of nitrogen dioxide in the production of sulfate during Chinese haze-aerosol episodes. Environ. Sci. Technol. 2018, 52, 2686-2693.

(18) Shao, J.; Chen, Q.; Wang, Y.; Lu, X.; He, P.; Sun, Y.; Shah, V.; Martin, R. V.; Philip, S.; Song, S.; Zhao, Y.; Xie, Z.; Zhang, L.; Alexander, B. Heterogeneous sulfate aerosol formation mechanisms during wintertime Chinese haze events: air quality model assessment using observations of sulfate oxygen isotopes in Beijing. Atmos. Chem. Phys. 2019, 19, 6107-6123.

(19) Nguyen, T. K. V.; Petters, M. D.; Suda, S. R.; Guo, H.; Weber, R. J.; Carlton, A. G. Trends in particle-phase liquid water during the Southern Oxidant and Aerosol Study. Atmos. Chem. Phys. 2014, 14, 10911-10930.

(20) Rader, D. J.; McMurry, P. H. Application of the tandem differential mobility analyzer to studies of droplet growth or evaporation. J. Aerosol Sci. 1986, 17, 771-787.

(21) Fountoukis, C.; Nenes, A. ISORROPIA II: a computationally efficient thermodynamic equilibrium model for $\mathrm{K}^{+}-\mathrm{Ca}^{2+}-\mathrm{Mg}^{2+}-\mathrm{NH}_{4}{ }^{+}-\mathrm{Na}^{+}-\mathrm{SO}_{4}{ }^{2-}-\mathrm{NO}_{3}{ }^{-}-\mathrm{Cl}^{-}-\mathrm{H}_{2} \mathrm{O}$ aerosols. Atmos. Chem. Phys. 2007, 7 , 4639-4659.

(22) Wexler, A. S.; Clegg, S. L. Atmospheric aerosol models for systems including the ions $\mathrm{H}^{+}, \mathrm{NH}_{4}^{+}$, $\mathrm{Na}^{+}, \mathrm{SO}_{4}{ }^{2-}, \mathrm{NO}_{3}{ }^{-}, \mathrm{Cl}^{-}, \mathrm{Br}^{-}$, and $\mathrm{H}_{2} \mathrm{O}$. J. Geophys. Res. Atmos. 2002, 107.

(23) Tan, H.; Cai, M.; Fan, Q.; Liu, L.; Li, F.; Chan, P. W.; Deng, X.; Wu, D. An analysis of aerosol liquid water content and related impact factors in Pearl River Delta. Sci. Total Environ. 2017, 579, 18221830.

(24) Freedman, M. A.; Ott, E.-J. E.; Marak, K. E. Role of $\mathrm{pH}$ in aerosol processes and measurement challenges. J. Phys. Chem. A 2019, 123, 1275-1284.

(25) Wei, H.; Vejerano, E. P.; Leng, W.; Huang, Q.; Willner, M. R.; Marr, L. C.; Vikesland, P. J. Aerosol microdroplets exhibit a stable pH gradient. Proc. Natl. Acad. Sci. U. S. A. 2018, 115, 7272-7277.

(26) Craig, R. L.; Peterson, P. K.; Nandy, L.; Lei, Z.; Hossain, M. A.; Camarena, S.; Dodson, R. A.; Cook, R. D.; Dutcher, C. S.; Ault, A. P. Direct determination of aerosol pH: size-resolved measurements of submicrometer and supermicrometer aqueous particles. Anal. Chem. 2018, 90, 11232-11239.

(27) Wang, Y.; Yao, L.; Wang, L.; Liu, Z.; Ji, D.; Tang, G.; Zhang, J.; Sun, Y.; Hu, B.; Xin, J. Mechanism for the formation of the January 2013 heavy haze pollution episode over central and eastern China. Sci. China Earth Sci. 2014, 57, 14-25.

(28) Wang, X.; Wang, W.; Yang, L.; Gao, X.; Nie, W.; Yu, Y.; Xu, P.; Zhou, Y.; Wang, Z. The secondary formation of inorganic aerosols in the droplet mode through heterogeneous aqueous reactions under haze conditions. Atmos. Environ. 2012, 63, 68-76.

(29) Sun, Y.; Chen, C.; Zhang, Y.; Xu, W.; Zhou, L.; Cheng, X.; Zheng, H.; Ji, D.; Li, J.; Tang, X.; $\mathrm{Fu}, \mathrm{P}$.; Wang, Z. Rapid formation and evolution of an extreme haze episode in Northern China during winter 2015. Sci. Rep. 2016, 6, 27151.

(30) Shi, G.; Xu, J.; Peng, X.; Xiao, Z.; Chen, K.; Tian, Y.; Guan, X.; Feng, Y.; Yu, H.; Nenes, A.; Russell, A. G. pH of aerosols in a polluted atmosphere: Source contributions to highly acidic aerosol. Environ. Sci. Technol. 2017, 51, 4289-4296. 
(31) He, P.; Alexander, B.; Geng, L.; Chi, X.; Fan, S.; Zhan, H.; Kang, H.; Zheng, G.; Cheng, Y.; Su, H.; Liu, C.; Xie, Z. Isotopic constraints on heterogeneous sulfate production in Beijing haze. Atmos. Chem. Phys. 2018, 18, 5515-5528.

(32) Liu, M.; Song, Y.; Zhou, T.; Xu, Z.; Yan, C.; Zheng, M.; Wu, Z.; Hu, M.; Wu, Y.; Zhu, T. Fine particle pH during severe haze episodes in northern China. Geophys. Res. Lett. 2017, 44, 5213-5221.

(33) Song, S.; Gao, M.; Xu, W.; Shao, J.; Shi, G.; Wang, S.; Wang, Y.; Sun, Y.; McElroy, M. B. Fineparticle $\mathrm{pH}$ for Beijing winter haze as inferred from different thermodynamic equilibrium models. Atmos. Chem. Phys. 2018, 18, 7423-7438.

(34) Guo, H.; Weber, R. J.; Nenes, A. High levels of ammonia do not raise fine particle pH sufficiently to yield nitrogen oxide-dominated sulfate production. Sci. Rep. 2017, 7, 12109.

(35) Tan, T.; Hu, M.; Li, M.; Guo, Q.; Wu, Y.; Fang, X.; Gu, F.; Wang, Y.; Wu, Z. New insight into $\mathrm{PM}_{2.5}$ pollution patterns in Beijing based on one-year measurement of chemical compositions. Sci. Total Environ. 2018, 621, 734-743.

(36) Zhao, M.; Wang, S.; Tan, J.; Hua, Y.; Wu, D.; Hao, J. Variation of urban atmospheric ammonia pollution and its relation with $\mathrm{PM}_{2.5}$ chemical property in winter of Beijing, China. Aerosol Air Qual. Res. 2016, 16, 1378-1389.

(37) Silver, B.; Reddington, C. L.; Arnold, S. R.; Spracklen, D. V. Substantial changes in air pollution across China during 2015-2017. Environ. Res. Lett. 2018, 13, 114012.

(38) Zheng, B.; Tong, D.; Li, M.; Liu, F.; Hong, C.; Geng, G.; Li, H.; Li, X.; Peng, L.; Qi, J.; Yan, L.; Zhang, Y.; Zhao, H.; Zheng, Y.; He, K.; Zhang, Q. Trends in China's anthropogenic emissions since 2010 as the consequence of clean air actions. Atmos. Chem. Phys. 2018, 18, 14095-14111.

(39) Liu, M.; Huang, X.; Song, Y.; Xu, T.; Wang, S.; Wu, Z.; Hu, M.; Zhang, L.; Zhang, Q.; Pan, Y.; $\mathrm{Liu}, \mathrm{X}$; Z Zhu, T. Rapid $\mathrm{SO}_{2}$ emission reductions significantly increase tropospheric ammonia concentrations over the North China Plain. Atmos. Chem. Phys. 2018, 18, 17933-17943.

(40) Shao, P.; Tian, H.; Sun, Y.; Liu, H.; Wu, B.; Liu, S.; Liu, X.; Wu, Y.; Liang, W.; Wang, Y.; Gao, J.; Xue, Y.; Bai, X.; Liu, W.; Lin, S.; Hu, G. Characterizing remarkable changes of severe haze events and chemical compositions in multi-size airborne particles $\left(\mathrm{PM}_{1}, \mathrm{PM}_{2.5}\right.$ and $\left.\mathrm{PM}_{10}\right)$ from January 2013 to 2016 2017 winter in Beijing, China. Atmos. Environ. 2018, 189, 133-144.

(41) Li, K.; Jacob, D. J.; Liao, H.; Shen, L.; Zhang, Q.; Bates, K. H. Anthropogenic drivers of 20132017 trends in summer surface ozone in China. Proc. Natl. Acad. Sci. U. S. A. 2019, 116, 422-427.

(42) Li, H.; Cheng, J.; Zhang, Q.; Zheng, B.; Zhang, Y.; Zheng, G.; He, K. Rapid transition in winter aerosol composition in Beijing from 2014 to 2017: response to clean air actions. Atmos. Chem. Phys. 2019, 19, 11485-11499.

(43) Zhai, S.; Jacob, D. J.; Wang, X.; Shen, L.; Li, K.; Zhang, Y.; Gui, K.; Zhao, T.; Liao, H. Fine particulate matter $\left(\mathrm{PM}_{2.5}\right)$ trends in China, 2013-2018: separating contributions from anthropogenic emissions and meteorology. Atmos. Chem. Phys. 2019, 19, 11031-11041.

(44) Weber, R. J.; Guo, H.; Russell, A. G.; Nenes, A. High aerosol acidity despite declining atmospheric sulfate concentrations over the past 15 years. Nat. Geosci. 2016, 9, 282.

(45) Tao, Y.; Murphy, J. G. The sensitivity of $\mathrm{PM}_{2.5}$ acidity to meteorological parameters and chemical composition changes: 10-year records from six Canadian monitoring sites. Atmos. Chem. Phys. 2019, 19, 9309-9320.

(46) Lawal, A. S.; Guan, X.; Liu, C.; Henneman, L. R. F.; Vasilakos, P.; Bhogineni, V.; Weber, R. J.; Nenes, A.; Russell, A. G. Linked response of aerosol acidity and ammonia to $\mathrm{SO}_{2}$ and $\mathrm{NO}_{\mathrm{x}}$ emissions reductions in the United States. Environ. Sci. Technol. 2018, 52, 9861-9873.

(47) Guo, H.; Nenes, A.; Weber, R. J. The underappreciated role of nonvolatile cations in aerosol ammonium-sulfate molar ratios. Atmos. Chem. Phys. 2018, 18, 17307-17323.

(48) Vasilakos, P.; Russell, A.; Weber, R.; Nenes, A. Understanding nitrate formation in a world with less sulfate. Atmos. Chem. Phys. 2018, 18, 12765-12775.

(49) Shah, V.; Jaeglé, L.; Thornton, J. A.; Lopez-Hilfiker, F. D.; Lee, B. H.; Schroder, J. C.; Campuzano-Jost, P.; Jimenez, J. L.; Guo, H.; Sullivan, A. P.; Weber, R. J.; Green, J. R.; Fiddler, M. N.; Bililign, S.; Campos, T. L.; Stell, M.; Weinheimer, A. J.; Montzka, D. D.; Brown, S. S. Chemical feedbacks 
weaken the wintertime response of particulate sulfate and nitrate to emissions reductions over the eastern United States. Proc. Natl. Acad. Sci. U. S. A. 2018, 115, 8110-8115.

(50) Battaglia, M. A.; Douglas, S.; Hennigan, C. J. Effect of the urban heat island on aerosol pH. Environ. Sci. Technol. 2017, 51, 13095-13103.

(51) Jia, S.; Wang, X.; Zhang, Q.; Sarkar, S.; Wu, L.; Huang, M.; Zhang, J.; Yang, L. Technical note: Comparison and interconversion of $\mathrm{pH}$ based on different standard states for aerosol acidity characterization. Atmos. Chem. Phys. 2018, 18, 11125-11133.

(52) Fountoukis, C.; Nenes, A.; Sullivan, A.; Weber, R.; Van Reken, T.; Fischer, M.; Matías, E.; Moya, M.; Farmer, D.; Cohen, R. C. Thermodynamic characterization of Mexico City aerosol during MILAGRO 2006. Atmos. Chem. Phys. 2009, 9, 2141-2156.

(53) Xu, W.; Sun, Y.; Wang, Q.; Zhao, J.; Wang, J.; Ge, X.; Xie, C.; Zhou, W.; Du, W.; Li, J.; Fu, P.; Wang, Z.; Worsnop, D. R.; Coe, H. Changes in aerosol chemistry from 2014 to 2016 in winter in Beijing: Insights from high-resolution aerosol mass spectrometry. J. Geophys. Res. Atmos. 2019, 124, 1132-1147.

(54) Bertram, A. K.; Martin, S. T.; Hanna, S. J.; Smith, M. L.; Bodsworth, A.; Chen, Q.; Kuwata, M.; Liu, A.; You, Y.; Zorn, S. R. Predicting the relative humidities of liquid-liquid phase separation, efflorescence, and deliquescence of mixed particles of ammonium sulfate, organic material, and water using the organic-to-sulfate mass ratio of the particle and the oxygen-to-carbon elemental ratio of the organic component. Atmos. Chem. Phys. 2011, 11, 10995-11006.

(55) Song, M.; Marcolli, C.; Krieger, U. K.; Zuend, A.; Peter, T. Liquid-liquid phase separation in aerosol particles: Dependence on O:C, organic functionalities, and compositional complexity. Geophys. Res. Lett. 2012, 39.

(56) Nenes, A.; Pandis, S. N.; Pilinis, C. ISORROPIA: A New Thermodynamic Equilibrium Model for Multiphase Multicomponent Inorganic Aerosols. Aquat. Geochem. 1998, 4, 123-152.

(57) Stokes, R. H.; Robinson, R. A. Interactions in aqueous nonelectrolyte solutions. I. solute-solvent equilibria. J. Phys. Chem. 1966, 70, 2126-2131.

(58) Zdanovskii, A. B. New methods for calculating solubilities of electrolytes in multicomponent systems. Zh. Fiz. Khim. 1948, 22, 1475-1485.

(59) Zhang, Y.; Seigneur, C.; Seinfeld, J. H.; Jacobson, M.; Clegg, S. L.; Binkowski, F. S. A comparative review of inorganic aerosol thermodynamic equilibrium modules: similarities, differences, and their likely causes. Atmos. Environ. 2000, 34, 117-137.

(60) Zaveri, R. A.; Easter, R. C.; Peters, L. K. A computationally efficient Multicomponent Equilibrium Solver for Aerosols (MESA). J. Geophys. Res. Atmos. 2005, 110.

(61) Topping, D. O.; McFiggans, G. B.; Coe, H. A curved multi-component aerosol hygroscopicity model framework: Part 1 - Inorganic compounds. Atmos. Chem. Phys. 2005, 5, 1205-1222.

(62) Jacobson, M. Z. Studying the effects of calcium and magnesium on size-distributed nitrate and ammonium with EQUISOLV II. Atmos. Environ. 1999, 33, 3635-3649.

(63) Hennigan, C. J.; Izumi, J.; Sullivan, A. P.; Weber, R. J.; Nenes, A. A critical evaluation of proxy methods used to estimate the acidity of atmospheric particles. Atmos. Chem. Phys. 2015, 15, 2775-2790.

(64) Friese, E.; Ebel, A. Temperature dependent thermodynamic model of the system $\mathrm{H}^{+}-\mathrm{NH}_{4}{ }^{+}-\mathrm{Na}^{+}-\mathrm{SO}_{4}{ }^{2-}-\mathrm{NO}_{3}{ }^{-}-\mathrm{Cl}^{-}-\mathrm{H}_{2} \mathrm{O}$. J. Phys. Chem. A 2010, $114,11595-11631$.

(65) Wang, Y.; Zhang, Q.; Jiang, J.; Zhou, W.; Wang, B.; He, K.; Duan, F.; Zhang, Q.; Philip, S.; Xie, Y. Enhanced sulfate formation during China's severe winter haze episode in January 2013 missing from current models. J. Geophys. Res. Atmos. 2014, 119, 10425-10440.

(66) Sun, Y.; Wang, Z.; Fu, P.; Jiang, Q.; Yang, T.; Li, J.; Ge, X. The impact of relative humidity on aerosol composition and evolution processes during wintertime in Beijing, China. Atmos. Environ. 2013, 77, 927-934.

(67) Li, G.; Bei, N.; Cao, J.; Huang, R.; Wu, J.; Feng, T.; Wang, Y.; Liu, S.; Zhang, Q.; Tie, X.; Molina, L. T. A possible pathway for rapid growth of sulfate during haze days in China. Atmos. Chem. Phys. 2017, $17,3301-3316$. 
(68) Ye, C.; Liu, P.; Ma, Z.; Xue, C.; Zhang, C.; Zhang, Y.; Liu, J.; Liu, C.; Sun, X.; Mu, Y. High $\mathrm{H}_{2} \mathrm{O}_{2}$ concentrations observed during haze periods during the winter in Beijing: Importance of $\mathrm{H}_{2} \mathrm{O}_{2}$ oxidation in sulfate formation. Environ. Sci. Technol. Lett. 2018, 5, 757-763.

(69) Li, H.; Zhang, Q.; Zhang, Q.; Chen, C.; Wang, L.; Wei, Z.; Zhou, S.; Parworth, C.; Zheng, B.; Canonaco, F.; Prévôt, A. S. H.; Chen, P.; Zhang, H.; Wallington, T. J.; He, K. Wintertime aerosol chemistry and haze evolution in an extremely polluted city of the North China Plain: significant contribution from coal and biomass combustion. Atmos. Chem. Phys. 2017, 17, 4751-4768.

(70) Cheng, N.; Cheng, B.; Li, S.; Ning, T. Effects of meteorology and emission reduction measures on air pollution in Beijing during heating seasons. Atmos. Pollut. Res. 2019, 10, 971-979.

(71) Cheng, J.; Su, J.; Cui, T.; Li, X.; Dong, X.; Sun, F.; Yang, Y.; Tong, D.; Zheng, Y.; Li, Y.; Li, J.; Zhang, Q.; He, K. Dominant role of emission reduction in PM2.5 air quality improvement in Beijing during 2013-2017: a model-based decomposition analysis. Atmos. Chem. Phys. 2019, 19, 6125-6146.

(72) Chen, Z.; Chen, D.; Wen, W.; Zhuang, Y.; Kwan, M. P.; Chen, B.; Zhao, B.; Yang, L.; Gao, B.; $\mathrm{Li}, \mathrm{R}$; $\mathrm{Xu}, \mathrm{B}$. Evaluating the " $2+26$ " regional strategy for air quality improvement during two air pollution alerts in Beijing: variations in PM2.5 concentrations, source apportionment, and the relative contribution of local emission and regional transport. Atmos. Chem. Phys. 2019, 19, 6879-6891.

(73) Rood, M. J.; Shaw, M. A.; Larson, T. V.; Covert, D. S. Ubiquitous nature of ambient metastable aerosol. Nature 1989, 337, 537-539.

(74) Seinfeld, J. H.; Pandis, S. N., Atmospheric chemistry and physics: from air pollution to climate change. Third ed.; John Wiley \& Sons, Inc.: Hoboken, New Jersey, 2016.

(75) Clegg, S. L.; Brimblecombe, P.; Wexler, A. S. Thermodynamic model of the system $\mathrm{H}^{+}-\mathrm{NH}_{4}{ }^{+}-\mathrm{Na}^{+}-\mathrm{SO}_{4}{ }^{2-}-\mathrm{NO}_{3}{ }^{-}-\mathrm{Cl}^{-}-\mathrm{H}_{2} \mathrm{O}$ at $298.15 \mathrm{~K}$. J. Phys. Chem. A 1998, 102, 2155-2171.

(76) Clegg, S. L.; Brimblecombe, P.; Wexler, A. S. Thermodynamic model of the system $\mathrm{H}^{+}-\mathrm{NH}_{4}{ }^{+}-\mathrm{SO}_{4}{ }^{2-}-\mathrm{NO}_{3}{ }^{-}-\mathrm{H}_{2} \mathrm{O}$ at tropospheric temperatures. J. Phys. Chem. A 1998, 102, 2137-2154.

(77) Po, H. N.; Senozan, N. M. The Henderson-Hasselbalch equation: its history and limitations. $J$. Chem. Educ. 2001, 78, 1499-1503.

(78) Peng, X.; Vasilakos, P.; Nenes, A.; Shi, G.; Qian, Y.; Shi, X.; Xiao, Z.; Chen, K.; Feng, Y.; Russell, A. G. Detailed analysis of estimated $\mathrm{pH}$, activity coefficients, and ion concentrations between the three aerosol thermodynamic models. Environ. Sci. Technol. 2019, 53, 8903-8913.

(79) Battaglia Jr, M. A.; Weber, R. J.; Nenes, A.; Hennigan, C. J. Effects of water-soluble organic carbon on aerosol pH. Atmos. Chem. Phys. Discuss. 2019, 2019, 1-36.

(80) Petters, M. D.; Kreidenweis, S. M. A single parameter representation of hygroscopic growth and cloud condensation nucleus activity. Atmos. Chem. Phys. 2007, 7, 1961-1971.

(81) Gen, M.; Zhang, R.; Huang, D. D.; Li, Y.; Chan, C. K. Heterogeneous oxidation of $\mathrm{SO}_{2}$ in sulfate production during nitrate photolysis at $300 \mathrm{~nm}$ : Effect of $\mathrm{pH}$, relative humidity, irradiation intensity, and the presence of organic compounds. Environ. Sci. Technol. 2019, 53, 8757-8766.

(82) Wang, Y.; Hu, M.; Guo, S.; Wang, Y.; Zheng, J.; Yang, Y.; Zhu, W.; Tang, R.; Li, X.; Liu, Y.; Le Breton, M.; Du, Z.; Shang, D.; Wu, Y.; Wu, Z.; Song, Y.; Lou, S.; Hallquist, M.; Yu, J. The secondary formation of organosulfates under interactions between biogenic emissions and anthropogenic pollutants in summer in Beijing. Atmos. Chem. Phys. 2018, 18, 10693-10713.

(83) Wang, S.; Zhou, S.; Tao, Y.; Tsui, W. G.; Ye, J.; Yu, J. Z.; Murphy, J. G.; McNeill, V. F.; Abbatt, J. P. D.; Chan, A. W. H. Organic peroxides and sulfur dioxide in aerosol: Source of particulate sulfate. Environ. Sci. Technol. 2019, 53, 10695-10704.

(84) An, Z.; Huang, R.-J.; Zhang, R.; Tie, X.; Li, G.; Cao, J.; Zhou, W.; Shi, Z.; Han, Y.; Gu, Z.; Ji, Y. Severe haze in northern China: A synergy of anthropogenic emissions and atmospheric processes. Proc. Natl. Acad. Sci. U. S. A. 2019.

(85) Hu, Q.; Yao, X. Reply to Comment on "identification of major sources of atmospheric $\mathrm{NH}_{3}$ in an urban environment in northern China during wintertime". Environ. Sci. Technol. 2018, 52, 364-365.

(86) Pan, Y.; Tian, S.; Liu, D.; Fang, Y.; Zhu, X.; Gao, M.; Gao, J.; Michalski, G.; Wang, Y. Isotopic evidence for enhanced fossil fuel sources of aerosol ammonium in the urban atmosphere. Environ. Pollut. 2018, 238, 942-947. 
(87) Pan, Y.; Tian, S.; Liu, D.; Fang, Y.; Zhu, X.; Zhang, Q.; Zheng, B.; Michalski, G.; Wang, Y. Fossil fuel combustion-related emissions dominate atmospheric ammonia sources during severe haze episodes: Evidence from 15N-stable isotope in size-resolved aerosol ammonium. Environ. Sci. Technol. 2016, 50, 8049-8056.

(88) Pan, Y.; Tian, S.; Liu, D.; Fang, Y.; Zhu, X.; Zhang, Q.; Zheng, B.; Michalski, G.; Wang, Y. Reply to Comment on "Fossil fuel combustion-related emissions dominate atmospheric ammonia sources during severe haze episodes: evidence from $15 \mathrm{~N}$-stable isotope in size-resolved aerosol ammonium". Environ. Sci. Technol. 2016, 50, 10767-10768.

(89) Teng, X.; Hu, Q.; Zhang, L.; Qi, J.; Shi, J.; Xie, H.; Gao, H.; Yao, X. Identification of major sources of atmospheric $\mathrm{NH}_{3}$ in an urban environment in northern China during wintertime. Environ. Sci. Technol. 2017, 51, 6839-6848.

(90) Wang, Q.; Zhang, Q.; Ma, Z.; Ge, B.; Xie, C.; Zhou, W.; Zhao, J.; Xu, W.; Du, W.; Fu, P.; Lee, J.; Nemitz, E.; Cowan, N.; Mullinger, N.; Cheng, X.; Zhou, L.; Yue, S.; Wang, Z.; Sun, Y. Temporal characteristics and vertical distribution of atmospheric ammonia and ammonium in winter in Beijing. Sci. Total Environ. 2019, 681, 226-234.

(91) Sun, K.; Tao, L.; Miller, D. J.; Pan, D.; Golston, L. M.; Zondlo, M. A.; Griffin, R. J.; Wallace, H. W.; Leong, Y. J.; Yang, M. M.; Zhang, Y.; Mauzerall, D. L.; Zhu, T. Vehicle emissions as an important urban ammonia source in the United States and China. Environ. Sci. Technol. 2017, 51, 2472-2481.

(92) Chang, Y.; Ma, H. Comment on "Fossil fuel combustion-related emissions dominate atmospheric ammonia sources during severe haze episodes: Evidence from $15 \mathrm{~N}$-stable isotope in size-resolved aerosol ammonium". Environ. Sci. Technol. 2016, 50, 10765-10766.

(93) Zeng, Y.; Wang, S. Comment on "Identification of major sources of atmospheric $\mathrm{NH}_{3}$ in an urban environment in northern China during wintertime". Environ. Sci. Technol. 2018, 52, 362-363.

(94) Zhang, L.; Chen, Y.; Zhao, Y.; Henze, D. K.; Zhu, L.; Song, Y.; Paulot, F.; Liu, X.; Pan, Y.; Lin, Y.; Huang, B. Agricultural ammonia emissions in China: reconciling bottom-up and top-down estimates. Atmos. Chem. Phys. 2018, 18, 339-355.

(95) Sun, W.; Shao, M.; Granier, C.; Liu, Y.; Ye, C. S.; Zheng, J. Y. Long-term trends of anthropogenic $\mathrm{SO}_{2}, \mathrm{NOx}, \mathrm{CO}$, and NMVOCs emissions in China. Earth's Future 2018, 6, 1112-1133. 